\title{
Exploring the Language of Vernacular Architecture in Today's Context: A Case of 'Kavunji,' India
}

\author{
Dr. Arulmalar Ramaraj, ${ }^{\dagger}$ Catherine Selvaraj’ and Sanghavi Venkata Varadan ${ }^{\sharp}$
}

\section{Abstract}

Globalisation, urbanisation, human neglect, socio-economic conditions, discontinuity, weather and climate have been identified from literature studies as the root causes hindering the vernacular architecture. The objective of this article is to explore such causes and impacts on vernacular architecture. For this purpose, 'Kavunji' a village near Kodaikanal, Tamilnadu is identified. Due to the geographical location and the landform, the vernacular architecture in this village is recently undergoing modifications and extensions. To comprehend the salient characteristics of vernacular architecture, six typologies were identified. The thrust of this paper is to explore the reasons that contributed to modifications and additions in dwelling units and effects on the people's attitude towards the maintenance of the built environment and form at regular intervals is declining rapidly as it requires tremendous efforts, fiscal resources, energy, and time. As a result, people are utilising modern materials to modify and extend the existing dwelling units, completely ignoring the essence of the context. The authors have identified syntactic analysis as a potential tool to comprehend the changes in the spatial relationship. With this as the focus, dwelling units limited to two-storeys with and without modifications were identified for an in-depth study. The semi-public space thinnai at the main entrance from the street is converted into a bathing space. Besides, additions of rooms occur only on the rear side of the dwelling unit. From this study, the authors reinstate that syntactic analysis effectively explores and interprets the efficiency of the spatial layout in dwelling units that have undergone modifications and additions.

Keywords: Vernacular Architecture; Kavunji; Kodaikanal, Tamilnadu; Western Ghats; India

\footnotetext{
${ }^{+}$Associate Professor, Department of Architecture, Sathyabama Institute of Science and Technology ,Chennai, India Email: arulmalar21@gmail.com

'Assistant Professor, Department of Architecture, Sathyabama Institute of Science and Technology , Chennai, India Email: cathyarchb4u@gmail.com

* Associate Professor, Department of Architecture,Sathyabama Institute of Science and Technology,Chennai, India

${ }^{*}$ Corresponding Author Email: sanghavi.vv@gmail.com

(C) 2021 Ramaraj et al. This is an Open Access article distributed under the terms of the Creative Commons Attribution License (http://creativecommons.org/licenses/by/2.0), which permits unrestricted use, distribution, and reproduction in any medium, provided the original work is properly cited.
} 


\section{Introduction}

When the term 'vernacular' is applied to architecture as 'vernacular architecture', it can be interpreted as the 'architectural language of the people with its ethnic, regional and local dialects' (Oliver, 2007). 'Vernacular', 'traditional' and 'folk' are the three terms that are the most commonly interchangeable terminologies within the sphere of vernacular architecture, that vary from one region to another (Hourigan,2015). Vernacular architecture has been categorised as the study 'buildings that are or were, the authentic product of a specific place and people, have evolved in form over time, and are produced by non-expert 'ordinary people' through shared knowledge passed down over time' (Brown and Maudlin,2012).

From the literature study, it is observed that vernacular architecture is an expression of both tangible and intangible factors specific to a context. These factors include social, cultural, geographical, economics, religion, spatial, physical, technological and aesthetic factors (Rapoport, 1969). The settlement and house forms have evolved over decades and demonstrate the cultural ethos of a community, the knowledge on planning, construction processes and techniques that have been developed over generations pragmatically. In this context, vernacular architecture is referred to as 'architecture without architects' (Rudofsky, 1987). Such practices have been transferred from one generation to another and in the process, have undergone tremendous developments and transformations. Vernacular architecture has been timeless and continuous in architectural development. In the current scenario, vernacular architecture is the emergent outcome of extensions and additions to a smaller unit, designed on-site and constructed by the user or by the local craftsmen celebrating the community's cultural values.

It is against this background, the authors have investigated the timeless and continuity of vernacular heritage at Kavunji, located near Kodaikanal, Tamilnadu, India. The objective of this article is to examine the ways through which the vernacular architecture has been effective in adapting to suit the needs and aspirations of the current generation. For this purpose, the authors have adopted syntactic analysis as an effective tool to comprehend and interpret the spatial relationship in today's context.

\section{Potential Strands to Explore Vernacular Architecture}

The authors have observed that the articles from the secondary resources depict that the 'vernacular' architecture is explored, as a key to the future. Researchers have been exploring, studying, synthesising and interpreting the vernacular expressions to unravel the hidden ideals in diverse directions. A study on the intent of 102 articles published on 'vernacular architecture' has been consolidated under various categories such as: 'vernacular settlement'; 'spatial configuration'; 'interpretation, identity and expressions'; 'hindrances to vernacular architecture'; 'interdisciplinary studies including landscape, planning, seismic'; 'sustainable building materials and construction techniques'; 'relating with modern architecture, climate \& energy' and 'education'. Papers on 'climate and energy' were observed to be around 25\%; 'sustainable building materials and construction techniques' accounted to be $18 \%$ whereas vernacular architecture as a model for modern architecture, spatial configuration, and interdisciplinary papers were determined to be $12 \%$ each. The revival and amalgamation of ideas derived from vernacular architecture in modern buildings tend to be disregarded. Besides, research projects that explicitly states and discusses the applications of vernacular knowledge in contemporary buildings are rare (Vellinga,2001). Papers on interpretation and identity of vernacular architecture, hindrances to vernacular architecture are around 5\% followed by studies on settlements and education which is around $4 \%$ each. From the survey, it is observed that there is a need to study the attributes hindering the vernacular architecture in the current scenario. The impacts of modifications and additions concerning dwelling 
units' spatial relationships have been identified as a potential strand for further study. This strand reinstates the need to comprehend the various factors that affect the vernacular architecture in today's context.

\section{An Insight into the Factors affecting Vernacular Architecture}

Threats to vernacular architecture have been broadly classified as natural and human-made hazards (Noble, 2013). Fire, wind, climate, volcanic eruptions, seasonal changes, earthquakes are the natural hazards. Humanmade hazards include wars, the people's mindset to adapt to modern life, policies and programmes framed by the Government to focus on protecting nature and the development of economic background.

According to Chuapram et al. (2012), the development of a hybrid economy focuses on multi-actor collaborations and organisations, societies, changing community structures and lifestyles has significantly contributed to the transformation of Thai vernacular houses around the Sogkhla Lake Basin. Discontinuities in building materials, social values, and attitudes regarding conservation and design interventions to extend and modify the typologies have been intimidating the culturally rich vernacular architecture (Philokyprou, 2015). Nonavailability of skilled labour and high expenditure involved in maintaining vernacular architecture has been the other attributes (Sadhu \& Ramesh, 2019). Evidence from other countries like Nigeria suggests that lack of funding for research works, human neglect, socio-economic condition, modernisation, discontinuity and climatic conditions hinder the vernacular architecture (Danja, 2019). Patidar \& Raghuwanshi(2014) have stated that globalisation and urbanisation have been posing severe threats to our country's cultural heritage. The lack of preservation consciousness, changes in the culture and yearning for contemporary lifestyle comfort in modern buildings have affected the vernacular architecture (Yildrim \& Korkmaz, 2012).

Liao (2016) and Liu et al. (2019) have identified that there has been a lack of studies exploring the transformation of vernacular architecture. It is against this background; this study focuses on the diverse factors that have posed severe threats to the vernacular dwellings and the construction practices in a rural settlement. This questions the spatial layout's efficiency that was once evolved is explored in two-storeyed dwelling units through syntactic analysis. The research design and the tool adopted in this article are descriptive case study and syntactic analysis respectively. The factors that facilitates the modifications and extensions limiting to two storied structures in a rural settlement, located along the slopes of Western Ghats, near 'Kodaikanal', is analysed.

\section{Methodology}

The term 'phenomenon' is used to address the topic identified as a study area (Hayes et al., 2015). The descriptive study focuses on describing a phenomenon and the characteristics (Nassaji, 2015); examines the situation as it prevails in its current state and identifies the related attributes (Williams, 2007). It generates both qualitative and quantitative data that define the status of the phenomenon identified for the study at a given point (Koh \& Owen, 2000). The case study discusses the existing condition of a phenomenon (Atmowardoyo, 2018). There is a need 'to begin with a descriptive theory to support the description of the phenomenon or story' (Zainal, 2007, p.3). A case study aims to describe a phenomenon with a rich detailed description, develop an explanation, and evaluate the same (Gall et al., 1996). An un-sequenced structure is often adopted to report the findings in descriptive studies; it is the researcher's role to address all the topics (Brown, 2008). A case study is 'an empirical inquiry that investigates a contemporary phenomenon within its real context, especially when the boundaries between phenomenon and context are not evident' (Yin, 2009,p.18). It is an in-depth, multifaceted investigation, using qualitative research methods (Feagin et al., 1991); a triangulated research strategy (Tellis, 1997); an empirical inquiry that investigates a phenomenon or a setting (Groat \& Wang, 2013). 
This methodology is adopted when answers to questions such as 'how' and 'why' are probed (Yin, 2009). It is particularly useful when rich knowledge about a situation or problem needs to be constructed (Noor, 2008). It generates context-dependent knowledge (Flyvbjerg, 2006; Widdowson, 2011); including qualitative and quantitative methods (Stjelja, 2013).

\section{The Study Area}

To meet the framed objective, a village 'Kavunji' located along the slopes of Western Ghats in Dindugul district with rich vernacular architecture but transforming in recent times is identified. 'Kavunji' means 'Kavuntha Vanji' which means bent Indian willow trees that were once flourishing in the valleys surrounding the settlement.

'Kavunji' is a village included in the Mannavanur Panchayat Union. The village is on the Western Ghats in Kodaikanal block of Dindugul district, Tamil Nadu, India. It is located $35 \mathrm{~km}$ from Kodaikanal at $10^{\circ} 12^{\prime} 26^{\prime \prime} \mathrm{N}$ longitude and $77^{\circ} 20^{\prime} 25^{\prime \prime}$ Elatitude. The temperature in the winter varies from $8.3^{\circ} \mathrm{C}$ to $17.3^{\circ} \mathrm{C}$ in the winter. It ranges from $11.3^{\circ} \mathrm{C}$ to $19.8^{\circ} \mathrm{C}$ with $16.5 \mathrm{~cm}$ as the annual precipitation in summer.

\section{The Settlement}

The village is divided into the higher and lower settlement, known as 'Mel Kavunji' and 'Kezh Kavunji'. 'Mel Kavunji' lies between the contours $1,990 \mathrm{~m}$ and $1,930 \mathrm{~m}$ above mean sea level and dwelling units have been constructed on the slopes leading to a valley. At 'Kezh Kavunji', the settlement has been planned between the contours $1900 \mathrm{~m}$ and $1910 \mathrm{~m}$ above the mean sea level. The geographical location of the lower settlement 'Kezh Kavunji' has been identified as a factor contributing significantly in retaining the vernacular character. However, in recent times, this village is growing, transforming and developing economically with the thrust on agriculture and tourism.

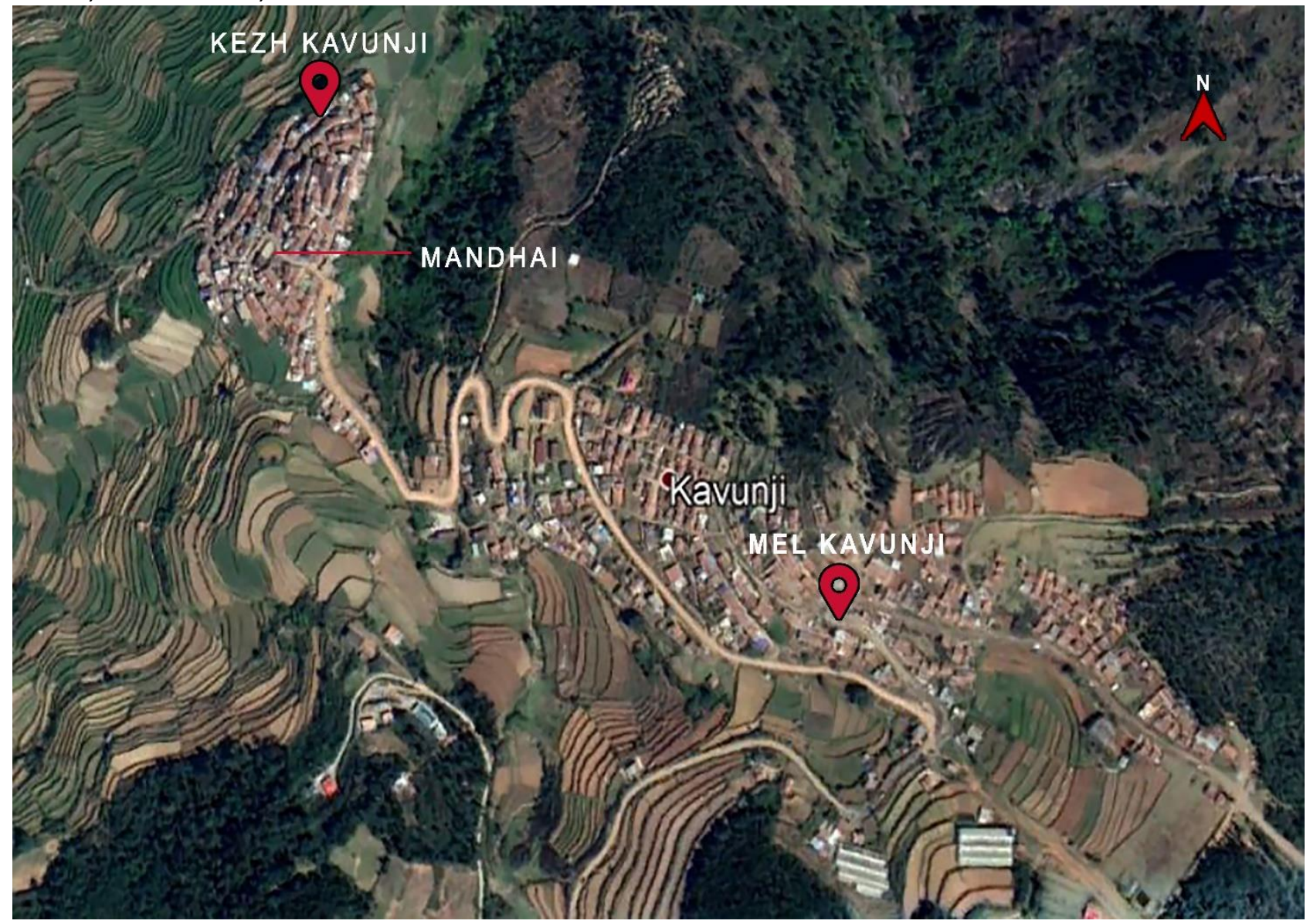

Figure 1: The Image of the Settlement from Google Earth Source: https://tinyurl.com/y3a9svd6 


\section{Data Collection and Analysis}

Primary data at the settlement was collected by the architecture students pursuing the third semester at Sathyabama Institute of Science and Technology as part of Architectural Design Studio III. Twenty-three students (11boys with an average age of 18.4 years; 12 girls with an average age of 18.6 years) from the batch 20172022 participated voluntarily to collect primary data, during the academic session June to November 2018. They stayed in the village for seven days from $12^{\text {th }}$ to $17^{\text {th }}$ July 2018 for documentation and collected data about the settlement and the dwelling units.

Data about the village were gathered from secondary sources like newspapers, databases such as 'Google', 'Google Scholar', 'Academia', 'Ebsco', 'Research gate' and 'Scopus'. Besides, at the settlement level, road network, classification of roads, land use, social infrastructure, age of buildings, roof type and the number of storeys were mapped.

Contours, figure and ground, services, road width to building height, materials used in constructing walls were mapped on the same scale for a comprehensive understanding of the lower settlement 'Kezh Kavunji' as well as the identification of the typologies. For understanding the architectural language, six typologies at 'Kezh Kavunji' were identified based on the tangible parameters such as the age of the building, altitude, distance from the central square, number of storeys, location in the windward or the leeward side, building materials, construction techniques and type of roofs. The intangible factors revolving around social aspects like caste system, economic status, customs, and beliefs were also gathered.

\section{Data Analysis}

Government policies and programmes for 'Kodaikanal' Municipality were synthesised to interpret the attributes that impacted the use of locally resourced building materials to construct, modify, and extend the dwelling units. At the micro-level, space syntax is adopted to quantify the spatial configuration in a building and interpret its underlying social logic (Hillier \& lida,
2005). The syntactic step is defined as the permeable relation between direction changes from one line to another (Min \& Yang, 2013). Depth of the overall building, the pattern of spatial organisation in the building, the degree of influence exerted by each space in the building and to understand the most integrated space and the least integrated space in the building is determined (Hillier, 2009). Comparing the values obtained through space syntax, the underlying intangible aspects of architecture are interpreted to trace the social logic.

For this purpose, the spaces' organisation was studied in detail and simplified to lines and circles to prepare 'justified or $\mathrm{j}$ - graphs. The spaces are represented as circles and connected with lines denoting the change of direction between the spaces. The line with a rhombus represents the staircase. Moreover, the modifications and additions of the spaces constructed with bricks, cement, steel, asbestos sheets and reinforced concrete are demarcated in square and rectangular profiles in the developed graphs as shown in Figures 3 (a) to (d).

Justified graphs for the two-storeyed buildings were mapped to understand the spatial relationship in the dwelling units. In the case of dwelling units accommodating more than one family, the spaces occupied by a single-family are considered. In this article, the term 'dwelling unit' is represented as 'D/U.' denoting single, or two-storied structures.

The calculated values for depth value (D), mean depth value $(M D)$, relative asymmetry (RA), real relative asymmetry (RRA), integration (I) and control value (CV) for all the two-storeyed D/U are calculated as put forth by Ostwald (2011). The depth values of the identified typologies are determined based on the root space's number of levels. The 'exterior' is the root spaces and is represented as 'zero.' The mean depth value $(M D)$, relative asymmetry (RA), real relative asymmetry (RRA), integration (I) and control value (CV) are determined using the equations $1,2,3,4$, and 5 respectively. 
Mean depth (MD)
Relative asymmetry (RA)
Real relative symmetry (RRA)

Integration (I)

Control value (CV)

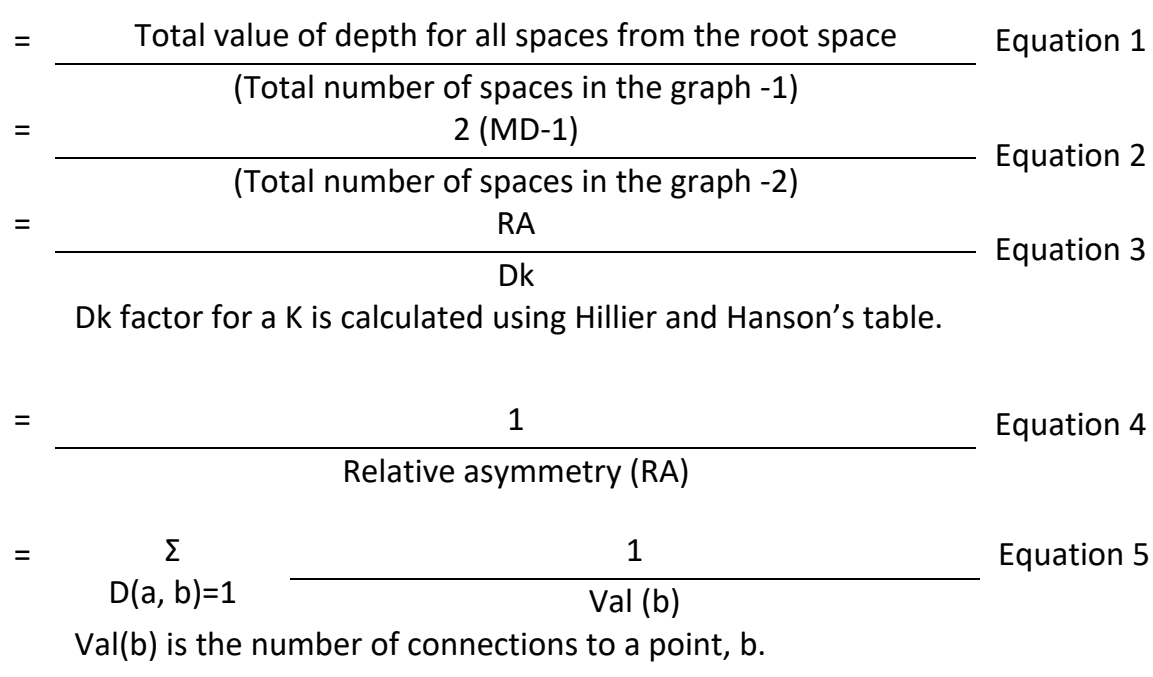

The degree of ornamentation that was manifested in the columns, doors and doorknobs, eaves, furniture such as showcase, cupboards and beds, was e qualitatively adopting the categories 'not applicable', 'simple, 'moderate' and 'good'. Depending on the frequency, 'degree of ornamentation' was classified as 'rich', 'above average' and 'average'.

\section{Findings}

The findings are addressed at two levels, at the settlement level, focusing on 'Kezh Kavunji' and at the 'built forms and interior spaces' to construct the 'big picture' of 'vernacular settlement' specific to the context.

\section{At the Settlement Level}

Only $1 \%$ of land use comprises commercial and public buildings like garlic storage areas; carrot washing areas. Nearly $89 \%$ of the houses had pitched roofs. Around $78 \%$ of the dwelling units have Mangalore tiles, nearly $11 \%$ are covered with asbestos, and the others have flat roofs. While analysing the buildings' age, $62 \%$ of the units are constructed in the last five decades. Approximately $17 \%$ of the dwelling units are 51 to 100 years old; $19 \%$ fall under 101 to 150 years old. Only $2 \%$ is more than 150 years, respectively.

\section{The Lower Settlement 'Kezh Kavunji'}

The lower settlement with the maximum number of vernacular buildings was delineated for the study purpose. The square (Mandhai) is located at the highest point. With the square as the centre, the dwelling units are constructed around it. The geographical conditions inhibit the expansion of the settlement naturally. It is observed that nearly $60 \%$ of the houses are constructed in slopes lesser than $10 \%$.

\section{The Central Square or 'Mandhai'}

The main feature in this settlement is the central square, 'Mandhai.'It is located at $1910 \mathrm{mfrom}$ the mean sea level, the highest point in the lower settlement. This square serves as the congregation space and is accessible to all. However, it was observed that there had been a distinct social stratification within the settlement. Along the steep slopes, underprivileged families had constructed the dwelling units. These units had two floors, the ground and the basement level. The elite families had constructed dwelling units along with the shallow contour levels.

\section{Spatial Organisation in a Typical Single Storey Unit}

Dwelling units are compact. In all the singlestoreyed D/Us, the main doors always open towards the right hand. As soon as one enters, the storage, kitchen, praying area occupies on the left-hand side, as shown in Figure 2. Besides, sleeping area and additional storage areas occur on the right side. Additional space for storing agricultural produce is designed above the cooking area. Right opposite to the main entrance, a showcase made of wood is present. 
Adjacent to the showcase, a door opens to the backyard.

The maximum width to length ratio of such units is around 0.9:1.0. It has been observed that spatial organisation has been the collective outcome with intentions to preserve the primary agricultural products and adapt to the extreme climatic conditions.

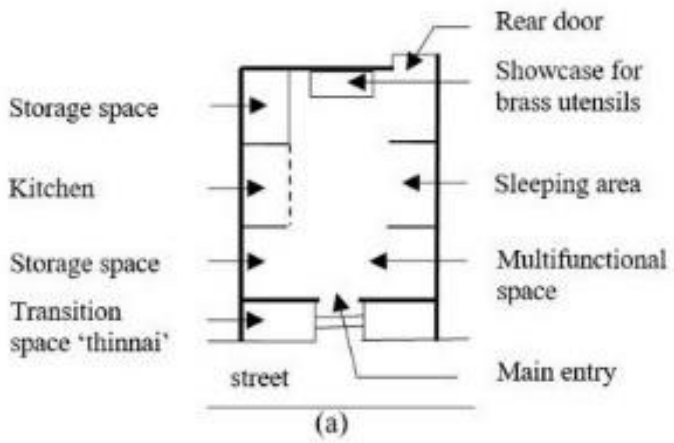

\section{Architectural Detailing to Preserve Garlic}

The cooking area is the hearth, as the smoke is very much needed to preserve 'garlic', which is hung from the numerous wooden poles that run along with both the longer and shorter sides of the D/U. Each time the door is opened cold and fresh air enters the $D / U$, whereas the hot air rises above the garlic layer and escapes through the gaps between the walls and the roofs.

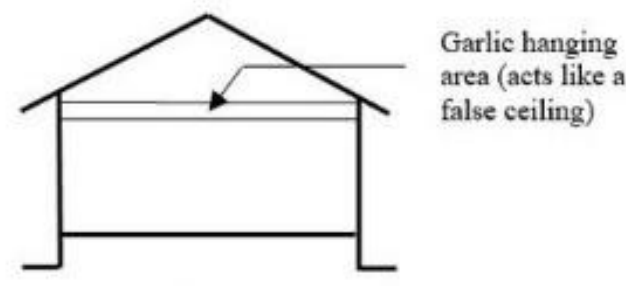

(b)

Figure 2: A Typical Single Storied Dwelling Unit (a) Plan (b) Section Source: Developed by the Authors through Primary Survey

\section{The Interiors and Ornamentation}

To preserve the primary agricultural produce, garlic, the interiors have poles fixed along both the longer and shorter sides. The poles are fixed in two layers with a gap of around $40 \mathrm{~cm}$ to hang the fresh garlic along with the shoots. This is exposed to the heat and smoke generated from the cooking range for a period of four to six months. Besides, this layer acts as a false ceiling. In some units, provisions are made to fix and remove poles to increase the storage volume. In $\mathrm{D} / \mathrm{U}$, where additional rooms are constructed with modern materials, people dwell in the areas built with locally available materials as such spaces are thermally comfortable. The light reflected by brass utensils illuminates the interiors.

In the two-storeyed twin D/Us for two families and two-storeyed tripartite $D / U$ for three families, the degree of ornamentation is rich as a minimum of six elements such as doors, doorknobs, eave boards, columns, showcases are categorised as 'good'. The units that are located near the central square portray the highest degree of ornamentation. The degree of ornamentation varies to the difference in contours between the central square and the D/Us that exhibit the social stratification deeply intertwined with society.

\section{An Insight into the Typologies}

Two storied D/Us predominantly had a ground and an attic floor as highlighted in Table1. Based on the parameters discussed above, six case studies are identified based on the location concerning the central square 'mandhai'. However, among the six typologies, only twostoreyed structures were identified to develop the justified graphs as well as to explore the spatial organisation through syntactic analysis.

\section{Spatial Analysis of Two-Storeyed D/Us}

Typically in a unit with a ground and an attic floor, the simple wooden staircase leading to the attic area is located right behind the main door. However, when width: length is around 1:2, the unit has two rooms on the ground floor. The first room is commonly observed in all $\mathrm{D} / \mathrm{Us}$ and the stairs to the basement are located in the second room. The spatial configurations of the twostoreyed dwelling units are shown graphically as 
justified graphs, where the exterior space is the root space denoted as 'zero' in Figure 3.

\begin{tabular}{|c|c|c|c|c|c|c|c|}
\hline \multicolumn{2}{|l|}{ Typology } & $\begin{array}{c}2 \\
\text { storeyed } \\
\text { Twin } \\
\text { D/U }\end{array}$ & $\begin{array}{c}2 \\
\text { storeyed } \\
D / U\end{array}$ & $\begin{array}{c}2 \\
\text { storeyed } \\
\text { tripartite } \\
\text { D/U }\end{array}$ & $\begin{array}{c}3 \\
\text { storeyed } \\
D / U\end{array}$ & $\begin{array}{c}\text { Wattle \& } \\
\text { daub } \\
\text { tripartite } \\
\text { D/U }\end{array}$ & $\begin{array}{c}2 \\
\text { storeyed } \\
\text { colony } \\
\text { D/U }\end{array}$ \\
\hline \multicolumn{2}{|c|}{ Families } & Two & One & \multicolumn{3}{|c|}{ Three } & One \\
\hline \multirow[b]{2}{*}{$\begin{array}{l}\text { Location } \\
\text { of } D / U \\
\text { with } \\
\text { respect } \\
\text { to the } \\
\text { central } \\
\text { square }\end{array}$} & Distance & $15 \mathrm{~m}$ & $30 m$ & $32 m$ & $40 m$ & $18 m$ & $35 \mathrm{~m}$ \\
\hline & $\begin{array}{l}\text { Level } \\
\text { difference }\end{array}$ & $-1 m$ & $-2.25 m$ & $-3.5 m$ & $-3.2 m$ & $-1.5 m$ & $-5.5 m$ \\
\hline \multicolumn{2}{|c|}{$\begin{array}{l}\text { Transition space at the } \\
\text { entrance }\end{array}$} & \multicolumn{5}{|c|}{ Present } & Absent \\
\hline \multicolumn{2}{|l|}{ Storey } & $\begin{array}{l}\text { Ground } \\
+ \text { attic }\end{array}$ & $\begin{array}{c}\text { Ground + } \\
\text { attic }\end{array}$ & $\begin{array}{l}\text { Ground + } \\
\text { basement }\end{array}$ & $\begin{array}{l}\text { Ground + } \\
\text { two floors }\end{array}$ & Ground & $\begin{array}{l}\text { Ground + } \\
\text { basement }\end{array}$ \\
\hline \multicolumn{2}{|l|}{ Entrance } & Ground & Ground & $\begin{array}{l}\text { Ground \& } \\
\text { basement }\end{array}$ & $\begin{array}{l}\text { Ground \& } \\
\text { basement }\end{array}$ & Ground & $\begin{array}{l}\text { Ground \& } \\
\text { basement }\end{array}$ \\
\hline \multirow{2}{*}{\multicolumn{2}{|c|}{ Addition / extension }} & & Extension & & Addition & \multirow{2}{*}{\multicolumn{2}{|c|}{ Not applicable }} \\
\hline & & $\begin{array}{c}\text { kitchen } \\
\& \\
\text { terrace }\end{array}$ & $\begin{array}{l}\text { bathroom } \\
\text { \&toilet }\end{array}$ & $\begin{array}{l}\text { Bedroom, } \\
\text { toilet }\end{array}$ & $\begin{array}{l}\text { bathroom } \\
\text { \&a toilet }\end{array}$ & & \\
\hline \multicolumn{2}{|c|}{ Ornamentation } & \multicolumn{2}{|c|}{ Rich } & \multicolumn{2}{|c|}{ Above Average } & \multicolumn{2}{|c|}{ Average } \\
\hline
\end{tabular}

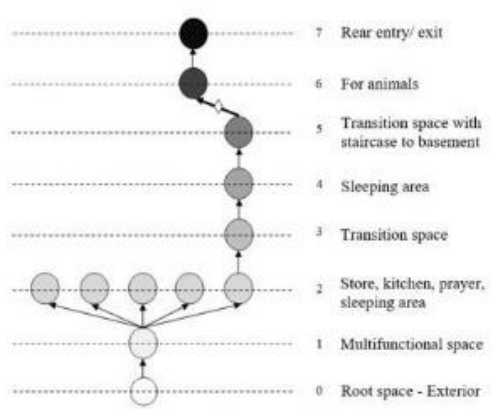

(a)

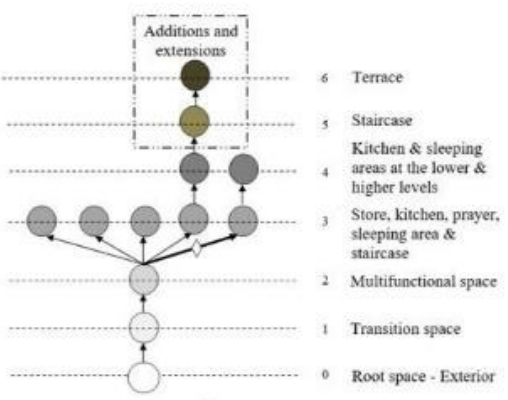

(c)

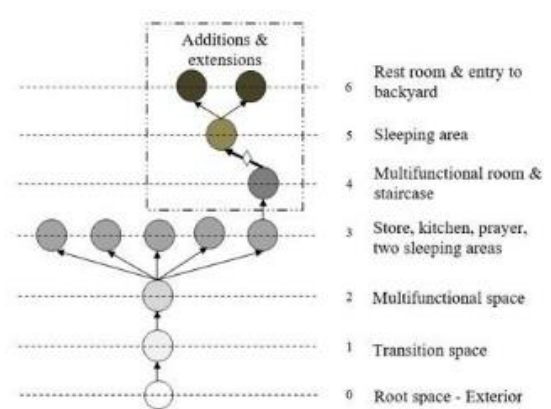

(b)

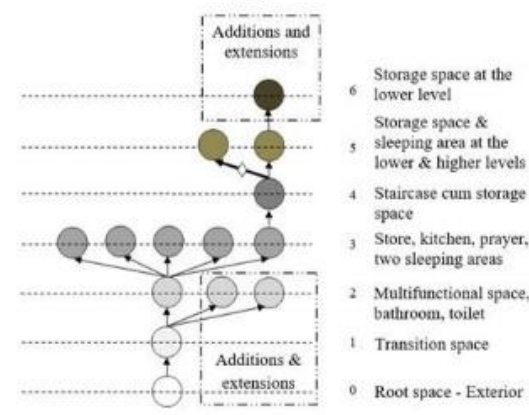

(d)

Figure 3: Justified graphs of two-storeyed dwelling units (a) G-1 Colony $D / U$ (b) G-1 $D / U$ (c) A part of $G+1$ twin $D / U$ (d) A part of $G+1$ tripartite $D / U$

Source: Developed by the Authors 
The values obtained for the identified twostoreyed units are as shown in Table 2. The higher values of Depth (D) and Control value (CV) portray that spaces are far away from the root space and the spaces are well connected respectively. The lower value of mean depth (MD) depicts the system to be shallow. However, when the value of Relative symmetry (RA) is less, the spaces are observed to be well integrated with the system.

\begin{tabular}{|c|c|c|c|c|c|}
\hline \multicolumn{2}{|l|}{ Typology } & $\begin{array}{l}2 \text { storied } \\
\text { colony D/U }\end{array}$ & $\begin{array}{l}2 \text { storied D/U } \\
\text { (modification } \\
\text { \& addition) }\end{array}$ & $\begin{array}{l}2 \text { storied } \\
\text { twin } D / U \\
\text { (addition) }\end{array}$ & $\begin{array}{l}2 \text { storied D/U } \\
\text { tripartite } \\
\text { (addition) }\end{array}$ \\
\hline \multicolumn{2}{|l|}{ Family } & \multicolumn{2}{|l|}{ Single } & Two & Three \\
\hline & & True form & \multicolumn{3}{|c|}{ Extended / Modified } \\
\hline \multicolumn{2}{|l|}{ Storeys } & \multicolumn{2}{|c|}{ Ground + basement } & \multicolumn{2}{|c|}{ Ground + attic } \\
\hline \multirow[t]{3}{*}{ Depth value (D) } & Minimum & 23 & 21 & 9 & 25 \\
\hline & Mean & 30.91 & 31.83 & 12.86 & 37.5 \\
\hline & Maximum & 47 & 43 & 16 & 45 \\
\hline \multirow{3}{*}{$\begin{array}{l}\text { Mean depth value } \\
\text { (MD) }\end{array}$} & Minimum & 2.3 & 1.91 & 1.50 & 2.27 \\
\hline & Mean & 3.09 & 2.89 & 2.14 & 3.41 \\
\hline & Maximum & 4.7 & 3.91 & 2.67 & 5 \\
\hline \multirow{3}{*}{$\begin{array}{l}\text { Relative } \\
\text { asymmetry (RA) }\end{array}$} & Minimum & 0.29 & 0.18 & 0.2 & 0.33 \\
\hline & Mean & 0.46 & 0.38 & 2.14 & 0.48 \\
\hline & Maximum & 0.82 & 0.58 & 0.67 & 0.80 \\
\hline \multirow[t]{3}{*}{ Integration (I) } & Minimum & 0.36 & 0.49 & 0.51 & 0.36 \\
\hline & Mean & 0.69 & 0.84 & 0.88 & 0.64 \\
\hline & Maximum & 1.02 & 1.57 & 1.70 & 1.12 \\
\hline \multirow[t]{3}{*}{ Control value (CV) } & Minimum & 0.17 & 0.14 & 0.33 & 0.25 \\
\hline & Mean & 1.00 & 0.8 & 1.14 & 0.96 \\
\hline & Maximum & 5.50 & 4.5 & 3.17 & 3.58 \\
\hline
\end{tabular}

Source: Determined by the Authors

\section{Two-Storeyed D/Us}

\section{'G-1' Colony $D / U$ without Transformations}

The $D / U$ located on the contours $5.5 \mathrm{~m}$ below the central square is a ' $\mathrm{G}-1$ ' structure. The transition space is absent in this typology as shown in Figure 3(a). However, one enters into the multifunctional room commonly observed in all D/Us that opens to another room, which houses the staircase leading to the room below where the animals are accommodated. There is an entrance on the rear side that is accessed by a street at the lower level.

\section{Exploring the Additions and Extensions in the Typologies}

\section{'G-1'D/U}

Figure 3(b) represents the justified graph of ' $G$ 1 ' typology, and the $D / U$ has been extended using reinforced concrete. This typology is located on the contours that are $3.5 \mathrm{~m}$ below the central square. Besides, the steep contours have facilitated the possibility of constructing a basement. The same syntax in Figure 3(b) 'twostoreyed colony $D / U$, is observed in this typology. However, at the basement level, an additional room with a toilet is constructed and there is a doorway leading to the backyard. Modern materials such as bricks, cement, 
concrete and reinforced cement concrete are used in the extension of the $D / U$.

\section{'G+1' twin $D / U$}

At $1 \mathrm{~m}$ below the central square is the 'twostoreyed twin $D / U$ '. This unit has an attic floor, and the justified graph is as in Figure 3(c). The attic space and the terrace are not connected, and that has increased the integration value. $A$ kitchen is added behind the multifunctional space that houses a staircase leading to the terrace. This part of the $D / U$ is constructed with modern materials.

\section{'G+1' Tripartite $D / U$}

The justified graph Figure $3(d)$ is developed from a $\mathrm{D} / \mathrm{U}$ located $2.25 \mathrm{~m}$ below the central square and $30 \mathrm{~m}$ away from the same. This is the only unit with an open space in the front. A secondary transition space is observed from where the multifunctional space, toilet and bathroom are accessed. Besides, a room is added on the rear side.

By exploring the additions and extensions of the three units, it is observed that the contours have played a significant role in expanding either horizontally or vertically. The expansion is predominantly in the ground and the first-floor level if there is scope for expansion. This is predominantly visible in units that were constructed in areas with a slope ratio 1:10. In steep areas, the unit is expanded on the rear side with a basement. Depending upon the family's economical background, the plot opposite to the existing unit is purchased to construct a $\mathrm{D} / \mathrm{U}$ with modern materials, however following the principles observed in the identified typologies.

\section{Modifications and Additions}

The villagers have extended the vernacular $D / U$ along the primary axis at the same level either in the front or the rear side. However, when the contours are steep, the $D / U$ is extended on the rear side with a basement below. Besides, in most of the units 'thinnai', the transition space is modified into a bathing area. The dwelling units have been extended based on the site extent. Besides, the extensions have been made randomly with new materials as shown in Figure
3. This portrays that the people are modifying the $D /$ Us to satisfy the growing needs such as private spaces for sleeping, bathing, and toilets. This has triggered the villagers to overlook the intangible values questioning the cultural identity that was once profoundly intertwined with the people's lifestyle.

\section{Discussion and Conclusion}

Literature studies have identified that urbanisation and globalisation have promoted the use of modern materials in the extension, modification, and construction of new buildings. Besides, the cost factor involved in the maintenance, non-availability of skilled labour and the limited natural building materials has affected the vernacular architecture. The initiatives to preserve the rich tradition are limited.

\section{Factors Hindering Vernacular Architecture at 'Kavunji'}

This article has explored the spatial organisation changes that have taken place through modifications and additions incorporated in the D/Us. It has been observed that the Government act, "Preservation of trees" in 1955 prohibited the cutting of trees in the forest. This has been identified as a significant threat to natural building materials' availability for carrying out the age-old construction practices. Secondly, the Government's initiatives to enhance agricultural practices have been strengthening the people's economical background. This initiative of the Government has been intangibly enhancing the economic background of the people.

Further, the reconstruction of 'mandhai', the Government's central square during the beginning of this century, has also triggered the people to use modern materials while constructing new or extending the vernacular D/Us. Besides, under the National Agriculture Development Programme, this village is identified as a corporate village. A mega cluster project 'precision farming project' by 'Tamilnadu Agricultural University' in 2008 has been introduced (Ramamoorthy, 2016).This has been significantly enhancing the people's economical conditions, which in turn have facilitated the 
modification and the extension of the age-old dwelling units with modern materials. Moreover, laying roads by the state government, identifying tourism spots near the village, constructing schools, public toilets, and infrastructure for the storage and preservation of agricultural produce such as carrots and garlic have also influenced the transformations of vernacular architecture.

In this study, the authors have identified that the human efforts, time, energy including funds spent for the maintenance of spaces that were once celebrated have been deeply questioned in today's materialistic context. Further, the conversion of 'thinnai' into a bathing space has questioned the informal social interactions that take place at the street level. Such modifications changed the typical morphology by hindering the visibility of rich ornamentation of the wooden columns and brackets. Based on the mean values obtained for 'Relative asymmetry' and 'integration' as shown in Figure 4, it is observed that the addition of rooms on the rear side of the house is either poorly or well integrated with the main $\mathrm{D} / \mathrm{U}$.

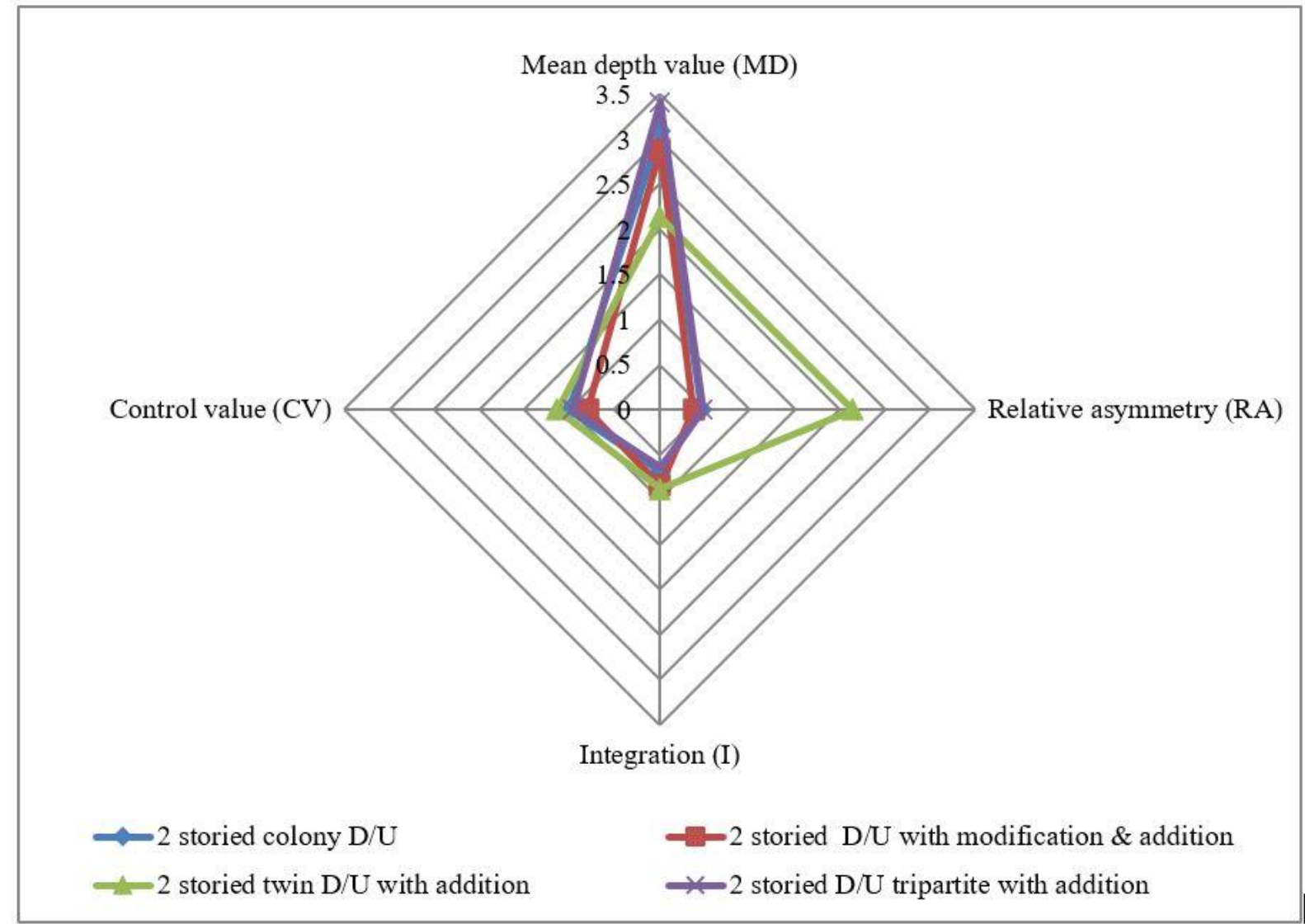

Figure 4: Mean value of mean depth value (MD), relative symmetry (RA), integration (I) and control value (CV) for two-storeyed D/Us Source: Developed by the Authors

\section{Interpreting the Syntactic Values}

Regarding the two-storeyed twin D/Us, the value of 'relative asymmetry' is observed to be the highest as the attic floor and terrace of the kitchen are not connected. This portrays that people have found ways to extend the floor area of the respective $D / U$ at the ground level only. The integration of the terrace as well as the attic floor, is challenging due to the use of modern materials. The value of relative symmetry is 0.48 in two-storeyed $\mathrm{D} / \mathrm{U}$ with the basement incorporating modifications and additions. This value displays that the added rooms are integrated well compared to the $D / U$ with an attic floor.

The authors have interpreted syntactic analysis as a potential tool to explore the spatial organisation's efficiency in vernacular dwelling 
units with modifications and transformations. Besides, the tactics adopted to extend the dwelling units along the Western Ghats slopes are also interpreted. It is against this background, the authors reinstate that syntactic analysis to be an effective tool to interpret the hidden dimensions of context-specific vernacular architecture in the current scenario. Besides, the syntactic analysis shall be used to explore the spatial organisation in temple complexes, palaces, forts etc, concerning time to construct rich descriptions from diverse perspectives.

\section{References}

Atmowardoyo, H. (2018). Research methods in TEFL studies: Descriptive research, case study, error analysis, and R \& D. Journal of Language Teaching and Research, 9(1), 197204. http://dx.doi.org/10.17507/jltr.0901.25

Brown, R., \& Maudlin, D. (2012). Concepts of vernacular architecture. The SAGE Handbook of Architectural Theory, 340-355.

http://dx.doi.org/10.4135/9781446201756.n21

Brown, P. A. (2008). A review of the literature on case study research. Canadian Journal for New Scholars in Education/Revue canadienne des jeuneschercheures et chercheursen education, 1(1).

Chuapram, S., King, R., \&Panin, O. (2012). Transformation of local living: Buddhist Thai communities and vernacular houses around Songkhla Lake basin. Procedia-Social and Behavioral Sciences, 50, 42-54. doi: 10.1016/j.sbspro.2012.08.014

Danja,I.I, Dalibi, S.G. \& Safarov,A. (2019). Hindrances to vernacular architecture of northern Nigeria, Global Journal of human Social Science: Sociology \& Culture, 19 (2), Accessed on $24^{\text {th }}$ April 2020.

Feagin, J. R., Orum, A. M., \& Sjoberg, G. (Eds.). (1991). A case for the case study. UNC Press Books.

Flyvbjerg, B. (2006). Five misunderstandings about case-study research. Qualitative Inquiry, 12(2), 219-245, doi: $10.1177 / 1077800405284363$
Gall, M. D., Borg, W. R., \& Gall, J. P. (1996). Educational research: An introduction. Longman Publishing.

Groat, L. N., \& Wang, D. (2013). Architectural research methods. John Wiley \& Sons.

Hayes, R., Kyer, B., \& Weber, E. (2015). The case study cookbook. Worcester Polytechnic Institute: Worcester, MA, USA.

Hillier, W. R. G., Hanson, J., \& Peponis, J. (1987). Syntactic analysis of settlements. Architecture and Behaviour, 3(3), 217-231.

Hillier, B., \& lida, S. (2005, September). Network and psychological effects in urban movement. In International Conference on Spatial Information Theory (pp. 475-490). Springer, Berlin, Heidelberg.

Hillier, B. (2009). Spatial sustainability in cities: Organic patterns and sustainable forms. Royal Institute of Technology (KTH).

Hourigan, N. (2015). Confronting classificationswhen and what is vernacular architecture. Civil Engineering and Architecture, 3(1), 22-30. doi: 10.13189/cea.2015.030104

Koh, E. T., \& Owen, W. L. (2000). Descriptive research and qualitative research. In Introduction to Nutrition and Health research (pp. 219-248). Springer, Boston, MA.

Liao, C. (2017). Rethinking the Vernacular in China: Understanding the Dynamics of Social Transformation and the Evolution of Rural Architecture (Doctoral dissertation, Columbia University). https://doi.org/10.7916/D8445ZKR

Liu, Q., Liao, Z., Wu, Y., Mulugeta Degefu, D., \& Zhang, Y. (2019). Cultural sustainability and vitality of Chinese vernacular architecture: $A$ pedigree for the spatial art of traditional villages in Jiangnan Region. Sustainability, 11(24), 6898. https://doi.org/10.3390/su11246898

Min, S., \& Yang, C. Y. (2013). A structural analysing model of sichuan vernacular dwelling. In Advanced Materials Research (Vol. 663, pp. 164-167). Trans Tech Publications Ltd. https://doi.org/10.4028/www.scientific.net/AM R.663.164 
Nassaji, H. (2015). Qualitative and descriptive research: Data type versus data analysis. https://doi.org/10.1177\%2F1362168815572747

Noble, A. (2013). Vernacular buildings: a global survey. Bloomsbury Publishing.

Noor, K. B. M. (2008). Case study: A strategic research methodology. American journal of applied sciences, 5(11), 1602-1604.

Ostwald, M. J. (2011). The mathematics of spatial configuration: Revisiting, revising and critiquing justified plan graph theory. Nexus Network Journal, 13(2), 445-470. https://doi.org/10.1007/s00004-011-0075-3

Oliver, P. (2007). Built to meet needs: Cultural issues in vernacular architecture. Routledge.

Patidat, S., \& Raghuwanshi, A. B. (2014). Changes in culture and architecture from vernacular to modern: MP, India. In Ahmedabad. International Plea Conference, Ahmedabad, December Ahmedabad, CEPT University (Vol. 8, pp. 16-19).

Philokyprou, M. (2015). Continuities and discontinuities in the vernacular architecture. Athens Journal of Architecture, 1(2), 111-120. https:// doi=10.30958/aja.1-2-2

Rapoport, A. (1969). House form and Cultua. London-University College: New Delhi: Prentice-hall of India Private Ltd, 73.

Ramamoorthy, D. R. R. (2016). An overview of the implementation of precision farming projects in Tamil Nadu, India.

Ravikumar, R. \&Gopu, J.A. (2016). An overview of precision farming projects in Tamilnadu, India, https://mpra.ub.unimuenchen.de/73674/1/MPRA_paper_73674.pd $\mathrm{f}$

Rudofsky, B. (1987). Architecture without architects: a short introduction to nonpedigreed architecture. UNM Press.Sadhu, V. K. K., \& Ramesh, S. (2020). People's Acceptance of Vernacular Houses-Transformed Dwellings of Ghantasala, Andhra Pradesh. Journal of World Architecture, 4(si1), 9-24. doi: 10.26689/jwa.v4isi1.920
Stjelja, M. (2013). The case study approach: Some theoretical, methodological and applied considerations (No. DSTO-TN-1188). Defence Science and Technology Organisation Edinburgh (Australia) Land Operations Div.

Tellis, W. (1997). Application of a case study methodology. The qualitative report, 3(3), 1-19.

Vellinga, M. (2006). Engaging the future: Vernacular architecture studies in the twentyfirst century. In Vernacular Architecture in the 21st Century (pp. 99-112). Taylor \& Francis.

Widdowson, M. D. J. (2011). Case study research methodology. International Journal of Transactional Analysis Research, 2(1), 25-34.

Williams, C. (2007). Research methods. Journal of Business \& Economics Research (JBER), 5(3). https://doi.org/10.19030/jber.v5i3.2532

Yildirim, M.\& Korkmaz, M (2012). Changes in built environment and in vernacular architecture through globalization: Case of Battalgazi in Turkiye, ERSA conference papers ersa, European Regional Science Association.

Yin, R. K. (2009). Case study research: Design and methods 4th edition. In United States: Library of Congress Cataloguing-in-Publication Data.

Zainal, Z. (2007). Case study as a research method. Jurnal Kemanusiaan, 5(1).

\section{Conflict of Interest Statement}

All of us have participated in (a) conception and design, or analysis and interpretation of the data; (b) drafting the article or revising it critically for important intellectual content; and (c) approval of the final version. We declare that this manuscript has not been submitted to, nor is under review in another journal or another publishing platform. We also have no affiliation with any organisation with a direct or indirect financial interest in the subject matter discussed in the manuscript. But all of us have affiliations with organisations with a direct or indirect financial interest in the subject matter discussed in the manuscript. 


\section{Author Contribution Statement}

Dr Arulmalar Ramaraj: Introduction, Methodology, Findings, Generating Graphs, Discussion and Conclusion.
Catherine Selvaraj: Methodology, Discussion and Conclusion and Preparation of Drawings.

Sanghavi Venkata Varadan(corresponding author): Methodology, Discussion and Conclusion and References. 